\title{
Prevalence of Bullying and Victimization Among Primary School Students of Higher Grades in Riyadh: a cross-sectional study
}

\section{Bander Haddad}

Imam Muhammad Ibn Saud Islamic University

Mohammed Al-Madi

Imam Muhammad Ibn Saud Islamic University

Moath Alsudais ( $\square$ MoathAlsudais@gmail.com )

Imam Muhammad Ibn Saud Islamic University https://orcid.org/0000-0001-7839-6541

Faisal AlMedimegh

Imam Muhammad Ibn Saud Islamic University

Saqer Alharthi

Imam Muhammad Ibn Saud Islamic University

Faisal Al-Oraini

Imam Muhammad Ibn Saud Islamic University

\section{Research article}

Keywords: Bullying, victimization, primary school, Saudi, Riyadh

Posted Date: March 24th, 2020

DOl: https://doi.org/10.21203/rs.3.rs-18753/v1

License: (c) (i) This work is licensed under a Creative Commons Attribution 4.0 International License. Read Full License

Version of Record: A version of this preprint was published at International Journal of Medicine in Developing Countries on January 1st, 2020. See the published version at https://doi.org/10.24911/IJMDC.51-1596284391. 


\section{Abstract}

Background: The current study aims to know the prevalence, effects and types of bullying at primary schools of Riyadh city for both male and female.

Methods: Male and female students at primary schools in Riyadh city are targeted using Cross-sectional study method. 517 students are included in this study $55.3 \%$ are female and $44.7 \%$ are male. Riyadh primary schools were divided into five groups according to geographic region North, South, East, West and Middle. The surveys were conducted after the approval of school's principals. In order to get an accurate response, the survey was distributed to student in classrooms in papers.

Results: 517 students participated in the study. Out of four regions the proportion from the Southern region were the highest at $187(36.2 \%)$. The levels of bullying and victimization was low. Compared to female students, male students showed statistically significant higher bullying and victimization rates. Compared to the five regions in Riyadh city the bullying and victimization rate is highest in the Eastern region, and lower in the southern region.

Conclusion: The study shows that the levels of bullying and victimization at Riyadh's primary schools was low. Furthermore, research studies about bullying and victimization prevalence rates are not enough and need more researches to improve the intervention and prevent the side effect of it.

\section{Background}

Bullying is known as aggressive behavior or acting in a way that brings intentional harm that when repeated over time includes an imbalance of power [1]. It can be categorizing into two groups, either direct or indirect. Direct bullying can be verbal (e.g. name-calling and threats) or physical (e.g. hitting and kicking). On the other hand, indirect bullying can be e.g. social exclusion or spreading rumors [2].

Effects of bullying have been associated with the victim not attending school [3] which could cause problems with achievements in their studies [4]. Bullying also could be associated with mental health problems [5-8] such as suicidal behavior and depression. The prevalence of bullying behavior varies across the country partly due to differences in the definition, age, gender, study design, and sample [9].

Bullying victims tend to suffer from anxiety and depression more than children who are not victimized [10 - 12]. An estimated $10 \%$ of school-aged children in the United States were bullied [13]. Other estimates show that $8 \%$ of students are bullied in Western Turkey, Asia [14].

A number of recent studies have been gathered about information on bullying based on self-reports [15, $16,17]$. Information from self-reports targeting higher grades of primary schools).

The aim of the study is to draw attention to the Education Ministry for further study into the prevalence and causes while raising awareness. This study is to also create more programs to address this issue as 
well as the source of the problem in primary schools. In addition, this study encourages more people to consider the causes of the result that we discovered.

\section{Methods}

Study design: A cross-sectional study conducted as a population-based.

Sample and population: Our targeted population is primary school students (age group 10-12) both male and female. After gathering the names of the primary schools in Riyadh, both males and females schools from Emirate of Riyadh website, we divided them into five categories according to regions: North (94 students), South (187 students), East (101 students), West (77 student) and Middle (58). The total of the subjects used for this study is 517 students. After that, the schools were chosen alphabetically and organized to select one school from each region by random selection using (Random.org) website. We were also permitted to conduct the surveys by schools' principals.

Questionnaire: A questionnaire from the book "Measuring Bullying Victimization, Perpetration, and Bystander Experiences: A Compendium of Assessment Tools" was used after permission was gained by its developer Thomas Tarshis, MD. The text was further translated to Arabic by a translator and reviewed and validated by a psychiatrist. The surveys were then distributed to students in their classrooms on paper to get an accurate response.

The questionnaire was designed to measure the distribution of bullies and victims on specific aspects among primary school students in Riyadh city.

Statistical analysis: The data were analyzed using the Statistical Package for Social Studies (SPSS 22; IBM Corp., New York, NY, USA). Continuous variables were expressed as mean \pm standard deviation and categorical variables were expressed as percentages. The t-test and One - way ANOVA was used for continuous variables. Cronbach's alpha was used to assess the reliability and internal consistency of the items in the questionnaire. A p-value $<0.05$ was considered statistically significant.

\section{Results}

We set out this cross-sectional survey study to find out the prevalence of bullying among primary school children in Riyadh, Saudi Arabia. For the questionnaire; Cronbach's alpha coefficient was calculated and had an overall score of 0.841 . When the coefficient was tested for every single question, in turn, using the "alpha if item deleted," no significant improvement was observed in the score. This reflects the excellent reliability and internal consistency of the items in the questionnaire.

The baseline characteristics of the study participants are shown in Table (1). The total number of students who participated in the current study was 517, more than half $286(55.3 \%)$ of them were females, while male gender represented $44.7 \%$, and the largest proportion aswas from the Southern 
region at $187(36.2 \%)$. For the age; $41 \%$ of the students were aged $\geq 12$ years, $30.9 \%$ were aged 11 years, and $28 \%$ were aged $\leq 10$ years. The highest percentage $(46.2 \%)$ of the respondents were in grade 6 .

The mean $( \pm S D)$ of all and each of the questionnaire items is shown in Table (2). For the victim subscale, the overall mean score was $5.34( \pm 4.64)$ out of 24 , and together with all the mean scores were occurring in the area between "never" and "sometimes", ranging from $0.23( \pm 0.54)$ to $0.68( \pm 0.71)$. The results revealed that the highest mean score (indicating more victimization) was for the point "other students tease me" at $0.68( \pm 0.71)$, followed by "other students take things from me that I do not want to give them" at $0.64( \pm 0.69)$, and "other students look at me in a mean way" at $0.56( \pm 0.68)$. On the other hand, the lowest scores were for the points: "I want to stay home from school because students are mean to me", "At recess, I play by myself", and "I am hit or kicked by other students" at $0.23( \pm 0.54), 0.25( \pm 0.53)$, and $0.29( \pm 0.54)$, respectively.

For the bully subscale, and similar to the victim subscale, all the mean scores were in the area between "never", and "sometimes", and were more near to "never", except for one point which was "I feel bad because I am mean to other students" at $1.08( \pm 0.87)$, which occurs in the area between "sometimes" and "many times". The mean score for this subscale items was the lowest for "I hit or kick other students" at $0.10( \pm 0.30)$, and the highest at $0.22( \pm 0.48)$ for the point "I push or slap other students", indicating more bully perpetration. Data is shown in Table 3.

The results of this study showed that the overall mean score of victimization is statistically significantly higher in males at $6.18( \pm 4.72)$, compared to females at $4.67( \pm 4.47)$, with a P-value of $<0.001$. Similar results were obtained for the bully subscale, since the overall mean score of males was $3.33( \pm 2.77)$, being significantly $(P<0.001)$ higher than females at $1.97( \pm 1.79)$, as shown in Table (3).

The mean of the victim subscale by students' characteristics is shown in Table 4 . The highest victimization score was shown among students from the eastern region with a mean of $6.31( \pm 5.20)$, while the lowest was from the western region at $3.91( \pm 4.67)$, with a statistically significant difference $(P<0.05)$ between the different study regions in terms of the victim subscale. Additionally; a statistically significant $(P<0.001)$ correlation between students' gender and the victim subscale was reported. Since males showed a statistically significant higher mean score than females at $6.18( \pm 4.72)$ vs $4.67( \pm 4.47)$, respectively. There was no significant correlation $(P>0.05)$ between victim subscale score and students' age or studying year, as shown in Table (4). Similar results were obtained for the bully subscale, where gender and region correlated significantly with it, while the age group and studying year did not. Bullying was the highest in the eastern region and the lowest in the southern one at $3.59( \pm 2.75)$ vs $2.06( \pm 1.56)$, respectively. Females showed significantly lower bullying than males at $1.97( \pm 1.79)$ compared to 3.33 $( \pm .77)$, respectively.

\section{Discussion}

School is considered a part of a micro-system for children after home that has a vital role in both social and emotional development. A child's experience at school can be assumed to have an effect on the 
learning process and their future life [19]. Reschly et al. showed that positive emotions felt during the school frequently associated with the higher engagement of children with learning, while other negative emotions are associated with low attachment [20]. Fredrickson reported in his study that positive emotions are a sign or an indicator of wellbeing and also form wellbeing in the future [21].

Bullying causes fear and suffering for the victims, and consists of verbal, physical, and psychological attacks performed repeatedly between parties where there are power imbalance and pressure from the powerful children to the less powerful ones, without any provocation from the victim [22]. Previous studies highlighted that bullies try to compensate for their inadequate self-confidence in this way [23], additionally, there is evidence about the relationship between bullying and unhappiness, lack of school love and even depression [24]. In current studies, it was found that the mean bully subscale is mostly near to "never". Such result is considered better compared to the results obtained from a study from Turkey in which children expressed that at least 2 times they attempted to bully and exposed to bullying 6 to 7 times [25]. Additionally, the prevalence of bullying among primary school children was estimated to be $13 \%$ in New Zealand [26].

Moreover, a national survey conducted in 40 western countries [27] reported rates of involvement in all the three groups of bullying (bullies, victims, bully-victims) combined at ranging from 4.8 to $45.2 \%$.

Differently, the findings of an Egyptian study revealed a markedly high prevalence (77.8\%) of bullying behavior among adolescent rural school students [28], and such high rates of violence were also detected by another study conducted among elementary school children [29]. Such variations in prevalence across countries could be attributed to the methodological and cultural differences in defining the problem and also to variations in target populations and the instruments used.

The current study revealed that there is a relationship between gender and both bullying and victimization, where males have significantly higher bullying and victimization rates. In accordance with these results, significantly higher bullying observed in males compared to females in studies conducted with primary school students [30-33]. Additionally, it was determined that our male students experienced physical and verbal bullying significantly compared to females, and this was in line with Demirbağ BC et al. study [25]. Female students in this study were less prone to be bullies and bully-victims, which could be attributed to cultural factors including that boys are less often punished for misbehavior compared to girls. Similarly, the studies of Cook et al. [34] and Yang et al. [35] found that bullying is more frequent in boys than girls. The fact that boys are more commonly involved in bullying does not necessarily mean they are more aggressive, but probably, they are more likely to adopt such behavior in an overt way such as physical bullying, whereas girls are frequently involved in forms of bullying that may be difficult to identify like gossiping, rejecting, teasing, verbal threatening, and humiliating [36].

In regards to the association between age with bullying behavior in previous studies, the prevalence of being bully-victims was significantly associated with younger age and preparatory grade, which could reflect that older age is a protective factor for involvement in bullying [37, 38]. In contrast to this, our study pointed out that bullying isn't significantly correlated with age. 
There is a paucity of prevalence studies on primary school bullying locations, forms and correlates in Saudi Arabia and even in the Arab world, which makes it difficult to compare our results or ascertain whether the problem is going from bad to better or from bad to worse. Future school bullying prevalence studies are required to project trends in the prevalence rates.

Almost all bullying research done internationally and in the United States has focused on bullying in elementary school, middle school, and high school. A review of this research showed that bullying and victimization are most common in elementary school and become progressively less common by the end of high school [39]. In primary schools, both in Western and non-Western countries, between $20 \%$ and $30 \%$ of the children are victims of bullying, while between $10 \%$ and $20 \%$ of the children are bullies [40].

In a previous study titled "The Peer Interaction in Primary School Questionnaire: testing for measurement equivalence and latent mean differences in bullying between gender in Egypt, Saudi Arabia and the USA" it was reported that Egyptian and Saudi boys/girls had a higher level of bullying compared to the American boys/girls, whereas no differences were displayed among the three cultures on the victimization subscale. Additionally, Boys had a higher level of bullying than girls in the three cultures, and boys and girls had a similar level of victimization in three cultures [41].

Bullying is considered a personal, social and educational problem, and identifying its possible risk factors, short and long term effects, and planning for prevention activities in the light of these findings seems one of the most important areas of research for children, families, and educators [42]. Teachers and families play an important role in the measures to be taken and interventions to be performed for the reduction and prevention of bullying type behaviors which have negative consequences for children such as not wanting to go to school, a decline in school achievements, and depression.

Ttofi and Farrington in their meta-analysis of 44 school-based intervention programs internationally, found that on average, these reduced bullying by around $20-23 \%$ and victimization by around $17-20 \%$; although there is considerable variation in outcomes [43]. They examined, across programs, which program components were most associated with success. They found that reducing victimization rates, videos, disciplinary methods, and parent training/meetings were most associated with success. While for reducing bullying, parent training/meetings, improved playground supervision, disciplinary methods, school conferences, information for parents, classroom rules, classroom management, and teacher training were most associated with success [43].

\section{Conclusion}

The study provides an overview of bullying and victimization among primary school children in Riyadh, Saudi Arabia. The levels of bullying and victimization were low. Male gender students showed statistically significant higher bullying and victimization rates as compared to females. The rates of bullying and victimization differed significantly between regions, the highest being in the Eastern one. Age and studying year did not significantly correlate with bullying or victimization. Despite the low rate of bullying and victimization reported in this study, intervention programs are still needed to prevent their 
side effects. Additionally, further research studies are needed to project trends in bullying and victimization prevalence rates.

\section{Declarations}

\section{Ethics approval and consent to participate}

Institutional Review Board (IRB) of Al-Imam Muhammad Ibn Saud Islamic University

Names of the ethics committee:

IRB chairman Prof. AbdulAziz Al-Akaabba

Vice-chairman: Dr. Arezki Azzi

Project number: 79-2019

Reference number: HAPO-01-R-001

We were verbally permitted to conduct the surveys by schools' principals for participants under 16 years old.

\section{Consent for publication}

Not applicable

\section{Availability of data and materials}

The datasets used and/or analysed during the current study are available from the corresponding author on reasonable request.

\section{Competing interests}

The authors declare that they have no competing interests.

\section{Funding}

Self-funded

\section{Authors' contributions}

$\mathrm{BH}$ validated data and information mentioned in the study and was a major contributor in writing the manuscript. MM was a major contributor in writing the manuscript and design of the work. MS was a major contributor in writing the manuscript and have made substantial contributions to the conception. FM have made substantial contributions to the conception and data acquisition. SH analyzed and 
interpreted the students' data regarding bullying and victimization. FO was a major contributor in data acquisition and analysis. All authors read and approved the final manuscript.

\section{Acknowledgment}

We would like to express our very great appreciation to The General Administration of Public Education in Riyadh and to the schools' directors. We also thank the school students who participated in the research.

Our special thanks are extended to Dr. Thomas Tarshis for the permission of using the questionnaire. We thank Prof. Abdul Aziz F. Al-Kaabba for his great advices and his role in reviewing the article.

Assistance in data collection provided by Atheer S. Al-Humaid, Hind A. Al-Abdullatif, Malak M. AlDakhilallah, Rahaf S. Al-Hudaib, Mohammed H. Al-Shehri, Omar A. Al-Ghamdi, Yaqoub Y. Al-Habib, and Rakan A. Al-Osaimi was greatly appreciated.

Finally, we would also want to extend our appreciation to those who could not be mentioned here.

\section{References}

1. Olweus D . Bullying at school:What we know and what can we do . Oxford:Blackwell ; 1993.

2. Bullying and victimization among 8-year-old children: A 16-year population-based time-trend study ANNA-MARJA ILOLA , ANDRE SOURANDER

3. Kubwalo HW, Muula AS, Siziya S, Pasupulati S, Rudatsikira E. Prevalence and correlates of being bullied among in-school adolescents in Malawi: results from the 2009 Global School-Based Health Survey. Malawi Med J 2013;25(1):12-4.

4. Boulton MJ, Trueman M, Murray L. Associations between peer victimization, fear of future victimization and disrupted concentration on class work among junior school pupils. Br J Educ Psychol 2008;78(Pt 3):473-89.

5. Hawker DS, Boulton M. Twenty years' research on peer victimization and psychosocial maladjustment: a metaanalytic review of cross Psychol Psychiatry 2000; 41(4):441-55.

6. Graham S, Bellmore AD, Mize J. Peer victimization, aggression, and their co-occurrence in middle school: pathways to adjustment problems. J Abnorm Child Psychol 2006;34(3):363-78.

7. Nishina A, Juvonen J, Witkow MR. Sticks and stones may break my bones, but names will make me feel sick: the psychosocial, somatic, and scholastic consequences of peer harassment. J Clin Child Adolesc Psychol 2005;34(1):37-48.

8. Storch EA, Nock MK, Masia-Warner C, Barlas ME. Peer victimization and social-psychological adjustment in Hispanic and African-American children. J Child Fam Stud 2003;12(4):439-52.

9. Lien L, Green K, Welander-Vatn A, Bjertness E. Mental and somatic health complaints associated with school bullying between 10th and 12th grade students; results from cross sectional studies in Oslo, Norway. Clin Pract Epidemiol Mental Health 2009;5:6. 
10. Santalahti P, Sourander A, Aromaa M, Helenius H, Ik ä heimo K, Piha J . Victimization and bullying among 8-year-old Finnish children:A 10-year comparison of rates . Eur Child Adolesc Psychiatry 2008; $17: 463-72$.

11. Arseneault $L$, Bowes $L$, Shakoor $S$. Bullying victimization in youths and mental health problems: “ Much ado about nothing?" Psychol Med 2010; $40: 717$ - 29 .

12. Juvonen $S$, Graham $S$, Schuster M . Bullying among young adolescents:The strong, the weak, and the troubled. Pediatrics 2003; $112: 1231-7$.

13. Sansone RA, Sansone LA. Bully victims: psychological and somatic aftermaths. Psychiatry (Edgmont) 2008;5 (6):62-4.

14. Arslan S, Hallett V, Akkas E, Akkas OA. Bullying and victimization among Turkish children and adolescents: examining prevalence and associated health symptoms. Eur J Pediatr 2012;171(10):154957.

15. Molcho M, Craig W, Due P, Pickett W, Harel-Fisch Y, Overpeck M et al . Cross-national time trends in bullying behaviour 1994 - 2006 : Findings from Europe and North America. Int J Public Health 2009; $54: 225-34$.

16. Schnohr C, Niclasen B . Bullying among Greenlandic schoolchildren:Development since 1994 and relations to health and health behaviour. Int J Circumpolar Health 2006; $65: 305-12$.

17. Luopa P, Pietik ä inen M, Jokela J . Koulukiusaaminen peruskoulun yl ä luokilla $2000-2007$ (School bullying in 8. and 9. grade of elementary school). Opetusministeri ö n julkaisuja $2008: 7$ (in Finnish).

18. Nordhagen $R$, Nielsen $A$, Stigum $H, K$ ö hler $L$. Parental reported bullying among Nordic children:A population-based study . Child Care Health Dev 2005; $31: 693-701$.

19. Alerby, E. (2003). During the break we have fun: A study concerning school children's experience of school. Educational Research, 45, 17-28.

20. Reschly, A.L., Huebner, E.S., Appleton, J.J., Antaramian, S. (2008). Engagement as flourishing: the contribution of positive emotions and coping to adolescent's engagement at school and with learning. Psychology in the Schools, 45(5).

21. Fredrickson, B.L. (2001). The role of positive emotions in positive psychology: The broaden-and-build theory of positive emotions. American Psychologist, 56 (3): 218-226

22. Nansel, T. R., Overpeck, M., Pilla, R. S., Ruan, W. J., Simons-Morton, B., \& Scheidt, P. (2001). Bullying behaviors among US youth: Prevalence and association with psychosocial adjustment. Jama, 285(16), 2094-2100.

23. Carney, A. G., \& Merrell, K. W. (2001). Bullying in schools Perspectives on understanding and preventing an international problem. School Psychology International, 22(3), 364-382.

24. Griffin, R. S., \& Gross, A. M. (2004). Childhood bullying: Current empirical findings and future directions for research. Aggression and Violent Behavior, 9(4), 379-400.

25. Demirbağ BC, Çiçek Z, Yiğitbaş Ç, Özkan ÇG, Dinçer A. The Relationship between Types of Bullying Experienced by Primary School Students and their Anxiety, State-Trait, Self-Esteem and Certain Socio- 
Demographic Characteristics. Procedia - Social and Behavioral Sciences. 2017 Feb 21; 237:398-404.

26. Raskauskas JL, Gregory J, Harvey ST, Rifshana F, Evans IM. Bullying among primary school children in New Zealand: relationships with prosocial behaviour and classroom climate. Educational Research. 2010 Mar 1; 52(1):1-13.

27. Craig W, Harel-Fisch Y, Fogel-Grinvald H, Dostaler S, Hetland J, Simons-Morton B, et al. A crossnational profile of bullying and victimization among adolescents in 40 countries. Int $\mathrm{J}$ Public Health. 2009; 54(2):216-44.

28. Galal YS, Emadeldin M, Mwafy MA. Prevalence and correlates of bullying and victimization among school students in rural Egypt. Journal of the Egyptian Public Health Association. 2019 Jun 7; 94(1):18.

29. Ez-Elarab HS, Sabbour SM, Gadallah MA, Asaad TA. Prevalence and risk factors of violence among elementary school children in Cairo. J Egypt Public Health Assoc. 2007; 82(1 \& 2):127-46.

30. Nabuzoka, D. (2003). Experiences of bullying-related behaviours by English and Zambian pupils: a comparative study. Educational Research, 45(1), 95-109.

31. Salmivalli, C., \& Nieminen, E. (2002). Proactive and reactive aggression among school bullies,

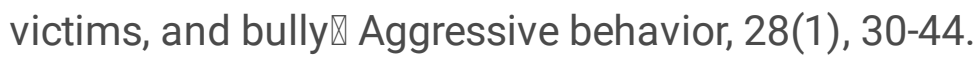

32. Seals, D., \& Young, J. (2003). Bullying and victimization: Prevalence and relationship to gender, grade level, ethnicity, self-esteem, and depression. Adolescence, 38(152), 735.

33. Warden, D., \& Mackinnon, S. (2003). Prosocial children, bullies and victims: An investigation of their sociometric status, empathy and social problem $\square$ solving strategies. British Journal of Developmental Psychology, 21(3), 367-385.

34. Cook CR, Williams KR, Guerra NG, Kim TE, Sadek S. Predictors of bullying and victimization in childhood and adolescence: a meta-analytic investigation. Sch Psychol Q. 2010; 25:65-83.

35. Yang SJ, Kim JM, Kim SW, Shin IS, Yoon JS. Bullying and victimization behaviors in boys and girls at South Korean primary schools. J Am Acad Child Adolesc Psychiatry. 2006; 45(1):69-77.

36. Bulach C, Fulbright JP, Williams R. Bullying behavior: what is the potential for violence at your school? J Instr Psychol. 2003; 30:156-64.

37. Eslea M, Rees J. At what age are children most likely to be bullied at school? Aggress Behav. 2001; 27:419-29.

38. Nansel TR, Overpeck M, Pilla RS, Ruan WJ, Simons-Morton B, Schedit P. Bullying behaviors among US youth: prevalence and association with psychosocial adjustment. J Am Med Assoc. 2001; 285:2094-100.

39. Nansel, T. R., Overpeck, M., Pilla, R. S., Ruan, W. J., Simons-Morton, B., \& Scheidt, P. (2001). Bullying behaviors among US youth prevalence and association with psychosocial adjustment. JAMA, 25, 2094-2100.

40. Smith, P. K., Morita, Y., Junger-Tas, J., Olweus, D., Catalano, R., \& Slee, P. (1999). The nature of school bullying: A cross-national perspective. London: Routledge 
41. Hussein MH. The Peer Interaction in Primary School Questionnaire: testing for measurement equivalence and latent mean differences in bullying between gender in Egypt, Saudi Arabia and the USA. Soc Psychol Educ. 2010 Mar 1;13(1):57-76.

42. O'Moore, M., \& Kirkham, C. (2001). Self-esteem and its relationship to bullying behaviour. Aggressive behavior, 27(4), 269-283.

43. Ttofi, M. M., and D. P. Farrington (2011), "Effectiveness of school-based programs to reduce bullying: a systematic and meta-analytic review", Journal of Experimental Criminology, 7, pp. 27-56.

\section{Tables}

Table1: Characteristics of the students

\begin{tabular}{|l|l|l|l|} 
& & Number & $\%$ \\
\hline Region & $\mathrm{E}$ & 101 & 19.5 \\
\hline & $\mathrm{W}$ & 77 & 14.9 \\
\hline & $\mathrm{N}$ & 94 & 18.2 \\
\hline & $\mathrm{S}$ & 187 & 36.2 \\
\hline & $\mathrm{M}$ & 58 & 11.2 \\
\hline Gender & Male & 231 & 44.7 \\
\hline & Female & 286 & 55.3 \\
\hline Age & $<=10 \mathrm{y}$ & 145 & 28.0 \\
\hline & $11 \mathrm{y}$ & 160 & 30.9 \\
\hline & $>=12 \mathrm{y}$ & 212 & 41.0 \\
\hline Studying year & Grade 4 & 146 & 28.2 \\
\hline & Grade 5 & 132 & 25.5 \\
\hline & Grade6 & 239 & 46.2 \\
\hline
\end{tabular}


Table2: Mean and Standard deviation for the questionnaire

\begin{tabular}{|l|l|l|}
\hline & Mean & SD \\
\hline Victim subscale & & \\
\hline 1. Other students make me cry & 0.45 & 0.56 \\
\hline 3. Other students take things from me that I do not want to give them & 0.64 & 0.69 \\
\hline 5. Other students look at me in a mean way & 0.56 & 0.68 \\
\hline 7. At recess, I play by myself & 0.25 & 0.53 \\
\hline 9. Another student tells me they will hurt me & 0.37 & 0.61 \\
\hline 11. I am hit or kicked by other students & 0.29 & 0.54 \\
\hline 13. Other students tease me & 0.68 & 0.71 \\
\hline 15. Other students ignore me on purpose & 0.42 & 0.62 \\
\hline 17. Other students make me feel sad & 0.51 & 0.65 \\
\hline 19. Other students make fun of me & 0.42 & 0.64 \\
\hline 20. I want to stay home from school because students are mean to me & 0.23 & 0.54 \\
\hline 22. Other students leave me out of games on purpose & 0.53 & 0.71 \\
\hline Overall Victim subscale (out of 24) \# & 5.34 & 4.64 \\
\hline Bully subscale & & \\
\hline 2. I tease other students & 0.20 & 0.46 \\
\hline 4. I push or slap other students & 0.22 & 0.48 \\
\hline 6. I tell other students I will hit or hurt them & 0.18 & 0.46 \\
\hline 8. I say mean things about a student to make other kids laugh & 0.20 & 0.40 \\
\hline 10. I make other students feel sad on purpose & 0.16 & 0.43 \\
\hline 12. I call other students bad names & 0.17 & 0.43 \\
\hline 14. I am mean to other students & 0.13 & 0.36 \\
\hline 16. I hit or kick other students & 0.10 & 0.30 \\
\hline 18. I feel bad because I am mean to other students & 1.08 & 0.87 \\
\hline 21. I give other students mean or "dirty" looks & 0.13 & 0.40 \\
\hline Overall Bully subscale (out of 20) & 2.58 & 2.38 \\
\hline & & \\
\hline
\end{tabular}




\begin{tabular}{|c|c|c|c|c|c|}
\hline & \multicolumn{2}{|l|}{ Male } & \multicolumn{2}{|c|}{ Female } & \multirow[t]{2}{*}{ P-value } \\
\hline & Mean & SD & Mean & SD & \\
\hline \multicolumn{6}{|l|}{ Victim subscale } \\
\hline 1. Other students make me cry & 0.41 & 0.53 & 0.49 & 0.58 & 0.126 \\
\hline 3. Other students take things from me that I do not want to give them & 0.58 & 0.72 & 0.69 & 0.66 & 0.067 \\
\hline 5. Other students look at me in a mean way & 0.62 & 0.72 & 0.50 & 0.65 & 0.059 \\
\hline 7. At recess, I play by myself & 0.26 & 0.53 & 0.24 & 0.53 & 0.694 \\
\hline 9. Another student tells me they will hurt me & 0.52 & 0.69 & 0.25 & 0.51 & $<0.001^{*}$ \\
\hline 11. I am hit or kicked by other students & 0.42 & 0.61 & 0.19 & 0.44 & $<0.001^{\star}$ \\
\hline 13. Other students tease me & 0.90 & 0.71 & 0.50 & 0.65 & $<0.001^{\star}$ \\
\hline 15. Other students ignore me on purpose & 0.43 & 0.62 & 0.42 & 0.62 & 0.820 \\
\hline 17. Other students make me feel sad & 0.59 & 0.68 & 0.44 & 0.61 & $0.008^{*}$ \\
\hline 19. Other students make fun of me & 0.56 & 0.69 & 0.31 & 0.57 & $<0.001^{*}$ \\
\hline $\begin{array}{l}\text { 20. I want to stay home from school because students are mean to } \\
\text { me }\end{array}$ & 0.29 & 0.60 & 0.17 & 0.48 & $0.011^{*}$ \\
\hline 22. Other students leave me out of games on purpose & 0.60 & 0.73 & 0.48 & 0.69 & 0.059 \\
\hline Over all Victim subscale (out of 24$)^{\#}$ & 6.18 & 4.72 & 4.67 & 4.47 & $<0.001^{\star}$ \\
\hline \multicolumn{6}{|l|}{ Bully subscale } \\
\hline 2. I tease other students & 0.29 & 0.55 & 0.12 & 0.35 & $<0.001^{*}$ \\
\hline 4. I push or slap other students & 0.29 & 0.53 & 0.17 & 0.43 & $0.008^{*}$ \\
\hline 6. I tell other students I will hit or hurt them & 0.32 & 0.58 & 0.07 & 0.29 & $<0.001^{*}$ \\
\hline 8. I say mean things about a student to make other kids laugh & 0.34 & 0.48 & 0.08 & 0.28 & $<0.001^{*}$ \\
\hline 10. I make other students feel sad on purpose & 0.24 & 0.52 & 0.09 & 0.32 & $<0.001^{*}$ \\
\hline 12. I call other students bad names & 0.29 & 0.54 & 0.06 & 0.26 & $<0.001^{*}$ \\
\hline 14. I am mean to other students & 0.21 & 0.43 & 0.07 & 0.29 & $<0.001^{*}$ \\
\hline 16. I hit or kick other students & 0.19 & 0.39 & 0.03 & 0.18 & $<0.001^{*}$ \\
\hline 18. I feel bad because I am mean to other students & 0.98 & 0.86 & 1.16 & 0.86 & $0.015^{\star}$ \\
\hline 21. I give other students mean or "dirty" looks & 0.18 & 0.47 & 0.09 & 0.34 & $0.018^{*}$ \\
\hline Overall Bully subscale (out of 20$)^{\$}$ & 3.33 & 2.77 & 1.97 & 1.79 & $<0.001^{*}$ \\
\hline
\end{tabular}

* Significant $p$ value $(p$ value $<0.05)$

\# Higher scores indicating more victimization

\$ Higher scores indicating more bully perpetration 
Table 4: Mean of Victim subscale by characteristics of the students

\begin{tabular}{|c|c|c|c|}
\hline & & Mean & SD \\
\hline \multirow[t]{5}{*}{ Region } & $E$ & 6.31 & 5.20 \\
\hline & $\bar{W}$ & 3.91 & 4.67 \\
\hline & $\mathrm{N}$ & 5.44 & 4.09 \\
\hline & S & 5.18 & 4.69 \\
\hline & $\bar{M}$ & 5.95 & 3.86 \\
\hline P-value & & \multicolumn{2}{|l|}{$0.011^{*}$} \\
\hline \multirow[t]{3}{*}{ Gender } & Male & 6.18 & 4.72 \\
\hline & Female & 4.67 & 4.47 \\
\hline & & \multicolumn{2}{|c|}{$<0.001^{\star}$} \\
\hline \multirow[t]{3}{*}{ Age } & $<=10 y$ & 5.71 & 4.85 \\
\hline & $11 \mathrm{y}$ & 4.93 & 4.67 \\
\hline & $>=12 y$ & 5.41 & 4.48 \\
\hline P-value & & \multicolumn{2}{|l|}{0.333} \\
\hline \multirow{3}{*}{ Studying year } & Grade 4 & 5.88 & 4.83 \\
\hline & Grade 5 & 4.62 & 4.64 \\
\hline & Grade6 & 5.42 & 4.50 \\
\hline P-value & & \multicolumn{2}{|l|}{0.075} \\
\hline
\end{tabular}

* Significant $p$ value $(p$ value $<0.05)$ 